\title{
Pendidikan Islam Anak Suku Bajo: Penelitian Lapangan pada Suku Bajo
}

\author{
H Herman ${ }^{1 凶}$ Laode Anhusadar $^{2}$ \\ Pendidikan Agama Islam, Institut Agama Islam Negeri Kendari, Indonesia(1) \\ Pendidikan Islam Anak Usia Dini, Institut Agama Islam Negeri Kendari, Indonesia (2) \\ DOI: $10.31004 /$ obsesi.v6i4.2266
}

\begin{abstract}
Abstrak
Kesadaran masyarakat suku bajo terhadap pendidikan anak usia dini masih rendah, terutama dalam pendidikan Islam untuk anak. Penelitian ini bertujuan untuk mengetahui pendidikan Islam anak, penanaman nilai-nilai keimanan, keteladanan dan pemberian nasehat Suku Bajo di Kecamatan Abeli Kendari. Penelitian ini merupakan penelitian lapangan yaitu penulis melakukan penelitian langsung ke lokasi untuk mendapatkan dan mengumpulkan data. Informan dalam tokoh agama, tokoh masyarakat, pendidik nonformal, dan anak. Teknik pengumpulan data dalam penelitian ini adalah wawancara, observasi dan dokumentasi. Teknis analisis data dalam penelitian ini dengan reduksi data, penyajian data dan penarikan kesimpulan. Hasil penelitian menyimpulkan bahwa pendidikan Islam masih tergolong rendah serta belum terlaksana dengan baik atau kualitas sumber daya manusia belum memenuhi target. Faktor pendukung pelaksanaan pendidikan Islam yaitu masyarakat suku Bajo di Kota Kendari seratus persen beragama Islam, dan perhatian pemerintah setempat sudah aktif memberikan fasilitas dan bantuan dalam rangka untuk menunjang kehidupan masyarakat Bajo.
\end{abstract}

Kata Kunci: pendidikan islam; suku bajo; anak usia dini.

\begin{abstract}
Bajo people's awareness of early childhood education is still low, especially in Islamic education for children. This study aims to determine the Islamic education of children, instilling life values, exemplary, and advising the Bajo Tribe in Abeli District, Kendari. This research is field research in which the author conducts research directly to the location to obtain and collect data. Informants in religious leaders, community leaders, non-formal educators, and children. Data collection techniques in this study were interviews, observation, and documentation. Technical analysis of data in this study with data reduction, data presentation, and concluding. The results of the study conclude that Islamic education is still relatively low and has not been implemented properly or the quality of human resources has not met the target. The supporting factor for the implementation of Islamic education is that the Bajo tribal community in Kendari City is one hundred percent Muslim, and the attention of the local government has been actively providing facilities and assistance to support the life of the Bajo community.
\end{abstract}

Keywords: islamic education; bajo tribe; early childhood.

Copyright (c) 2022 H Herman, Laode Anhusadar

$\triangle$ Corresponding author:

Email Address : herman33333@yahoo.com (Kendari, Indonesia)

Received 10 October 2021, Accepted 23 January 2022, Published 26 January 2022 


\section{PENDAHULUAN}

Anak usia dini didefinisikan oleh The National Association for the Education of Young Children (NAEYC) adalah anak yang berusia 0 sampai 8 tahun (Christianti, 2015). Menurut Illahi dalam Chairilsyah, anak memiliki karakteristik tertentu tidak sama dengan orang dewasa, rasa ingin tahu, antusias, dinamis dan selalu aktif terhadap apa yang dilihat, didengar, dirasakan, mereka selalu bereksplorasi dan belajar dalam kesehariannya (Chairilsyah, 2019). Karakteristik anak di Indonesia memiliki keanekaragaman yang berbeda menyesuaikan dengan keberadaan masyarakat. Masyarakat Indonesia adalah masyarakat majemuk yang ditandai oleh adanya kesatuan sosial yang memiliki perbedaan latar belakang yang beragam seperti suku bangsa, agama, adat istiadat dan budaya serta lingkungan geografis yang berbeda-beda. Keanekaragaman suku di Indonesia salah satunya adalah suku Bajo. Begitu pula komunitas Suku Bajo yang saat ini semakin menyatu dengan masyarakat secara umum untuk tinggal di daratan pesisir pantai. Komunitas suku Bajo seringkali disebut dengan istilah orang laut yang memiliki territorial. Suku Bajo (orang bajo) masih sering dianggap cukup sulit untuk menyatu dengan masyarakat sekitar karena mereka sudah terbiasa hidup pada lingkungan laut.

Dapat diketahui, Suku Bajo telah menempati hampir semua pesisir pantai di Indonesia sejak ratusan tahun silam. Bahkan menurut Poelinggomang, Orang Bajo sejak beberapa abad lalu sudah ditemukan di pesisir pantai pulau-pulau yang ada di Laut Cina Selatan. Meskipun dalam paparan dosen jurusan Ilmu Sejarah di Fakultas Sastra Univesristas Hasanudddin tentang 'Suku Bajo dan Persebarannya di Nusantara' dalam Dialog Budaya di Festival Seni Suku Bajo Internasional, di Gedung Mulo Mini Hall Kantor Dinas Kebudayaan dan Pariwisata Provinsi Sulawesi Selatan, juga masih cenderung mengikuti hasil penelitian bahwa asal-usul suku Bajo berasal dari Johor, Malaysia (Poelinggomang, 2016). Suku Bajo merupakan suku tertinggal dan minoritas di Indonesia dari aspek pendidikan, ekonomi, sosial. Data sensus penduduk pada tahun 2000, estimasi total populasi suku Bajo di Asia Tenggara sekita1.077.020 jiwa, dimana; 570.857 jiwa di Pilipina, 347.193 jiwa di Malaysia, dan 158.970 jiwa di wilayah Indonesia. Saladin S. Teo menyoroti pendidikan dan gaya hidup orang Bajo menyimpulkan bahwa secara umum perkembangan ilmu pengetahuan, kemajuan teknologi serta perubahan sosial tidak banyak mempengaruhi perubahan suku Bajo, termasuk aspek pendidikan dibandingkan dengan kelompok minoritas lainnya (Machmud et al., 2020).

Suku Bajo adalah sekelompok orang yang telah lama hidup bersama, bermukim tidak jauh dari pantai dengan mata pencaharian utamanya adalah mencari hasil laut yang jauh dari permukiman mereka. Sebagai masyarakat yang tinggal di pesisir pantai dan menggantungkan kehidupan mereka pada hasil laut berupa ikan, udang dan rumput laut, maka aktivitas masyarakat Bajo yang tinggal di pesisir pantai hampir semua waktunya di laut. Suku bajo mengantungkan kehidupannya dari sumber daya kelautan. Anak yang ada di suku bajo utama sejak usia dini telah didik dengan kondisi alam yang menuntutnya untuk mandiri (Hewi, 2015).

Pendidikan Islam pada dasarnya merupakan upaya pembinaan dan pengembangan potensi manusia agar tujuan kehadirannya di dunia ini sebagai hamba Allah swt, dan sekaligus sebagai khalifah, tercapai dengan baik. Potensi yang dimaksud meliputi potensi jasmani dan rohani, seperti akal, perasaan, kehendak, dan aspek rohaniah lainnya. Menurut Achmadi dalam wujudnya, pendidikan Islam dapat menjadi upaya agar pendidik secara bersama dalam memfasilitasi terjadinya proses pendidikan, Ruang lingkup pendidikan Islam meliputi keseluruhan ajaran Islam yang terpadu pada keimanan (akidah), ibadah, akhlak dan muamalah yang implikasinya mempengaruhi proses berpikir, merasa, berbuat serta terbentuknya kepribadian peserta didik yang pada gilirannya akan terwujud akhlakul karimah sebagai wujud manusia muslim (Musya' Adah, 2020).

Pendidikan Islam diarahkan untuk membangun karakter bangsa yang tinggi, serta mencetak anak yang memiliki akhlak dan keterampilan. Pernyataan di atas, pembentukan karakter Islami anak sangat penting, karena karakter Islami pada anak tidak akan mudah 
untuk diubah sampai anak tersebut dewasa nantinya, sehingga karakter inilah yang akan menjadi suatu penanda bahwa mereka adalah masyarakat muslim yang taat (Dozan \& Fitriani, 2020). sejalan dengan rumusan konsep pembaharuan pendidikan islam menurut Fazlurrahman, melibatkan 3 (tiga) pendekatan, yaitu: 1) Mengislamkan pendidikan sekuler modern; 2) Menyederhanakan silabus-silabus dalam rangka pendidikan tradisional; 3) Menggabungkan cabang-cabang ilmu pengetahuan. Melalui tiga pendekatan ini, fazlurrahman berargumen bahwa pendidikan Islam akan semakin berkembangan dan individu-individu (Muslim) dapat terhindar dari (split personality) atau pribadi-pribadi yang terpecah-pecah (Saihu, 2020).

Hasil-hasil studi tentang Tingkat partisipasi suku Bajo terhadap pendidikan Islam sangat rendah karena budaya yang berkonsentrasi di laut, anak usia lima belas tahun ke atas diikutkan ke laut, masih kurangnya sosialisasi tentang pentingnya ilmu pengetahuan dan teknologi (IPTEKS), lamban dalam berbaur, sebagian masih miskin dan belum ada kesadaran untuk berubah (Katutu, 2016). Terdapat 4 faktor penyebab putus sekolah dan rendahnya tingkat pendidikan di suku Bajo yakni faktor motivasi, sosial, ekonomi dan motivasi orang tua (Ikhsan et al., 2020). Berdasarkan hasil observasi awal yang penulis lakukan maka ditemukan fakta empiris bahwa pendidikan Islam pada anak Suku Bajo di Kecamatan Abeli kendari masih terkesan belum terlaksana dengan baik, sehingga kurang berimplikasi pada pembentukan akhlak anak. Selain itu, pendidikan Islam belakangan ini khususnya pada anak Suku Bajo, terasa kurang mengarah kepada pembentukan akhlak. Pendidikan kurang menekankan adanya keseimbangan antara aspek spiritual dengan intelektual, sehingga produk pendidikan tidak sesuai dengan harapan. Dengan fenomena tersebut, maka peneliti tertarik untuk melihat pendidikan Islam anak suku bajo khusunya pada anak yang ada pada rentang anak usia dini khususnya pada anak usia 4-8 tahun.

\section{METODOLOGI}

Penelitian ini merupakan penelitian lapangan atau field research, yaitu penulis melakukan penelitian langsung ke lokasi untuk mendapatkan dan mengumpulkan data. Menurut Moleong jenis penelitian ini adalah kualitatif, yakni penelitian yang dimaksudkan untuk memahami fenomena tentang apa yang dialami oleh subjek penelitian menghasilkan data deskriptif berupa kata-kata yang tertulis atau lisan dari orang-orang dan perilaku yang diamati. Dengan demikian, maka dapat dikatakan bahwa penelitian ini bersifat deskriptif kualitatif. Artinya, penulis menganalisis dan menggambarkan penelitian secara objektif dan mendetail untuk mendapatkan hasil yang akurat (Mastuti, 2014). Secara teoretis, Moleong mengungkapkan penelitian deskriptif adalah penelitian yang bermaksud untuk mengumpulkan informasi mengenai status suatu gejala yang ada, yaitu keadaan gejala menurut apa adanya pada saat dilakukan suatu penelitian, sehingga hanya merupakan penyingkapan fakta dengan menganalisis data (Khadijah \& Amelia, 2020). Penelitian ini berlokasi di Kecamatan Abeli Kendari khususnya pada pendidkkan Islam anak Suku Bajo. Informan dalam penelitian adalah orang-orang yang dianggap dapat memberikan keterangan yang aktual dan akurat dalam hal ini, tokoh agama, tokoh masyarakat, pendidik nonformal, dan anak pada Suku Bajo di Kecamatan Abeli Kendari, informan pada penelitian ini ditentukan dengan snowball sampling. Menurut sugiyono snowball sampling merupakan teknik penentuan sampel yang mulamula jumlahnya kecil, kemudian membesar (Shaleh \& Anhusadar, 2021). Teknik pengumpulan data dalam penelitian ini adalah wawancara, observasi dan dokumentasi. Penelitian ini dilakukan selama 6 bulan, peneliti melakukan wawancara langsung kepada informan serta melakukan pengamatan langsung terkait obyek penelitian. Teknik analisis dalam penelitian ini yaitu Analysis Interactive Model Miles \& Huberman terdiri dari data collection (pengumpulan data), data reduction (reduksi data), data display (penyajian data), dan conclutions (penarikan kesimpulan)(Ayuni et al., 2021). 


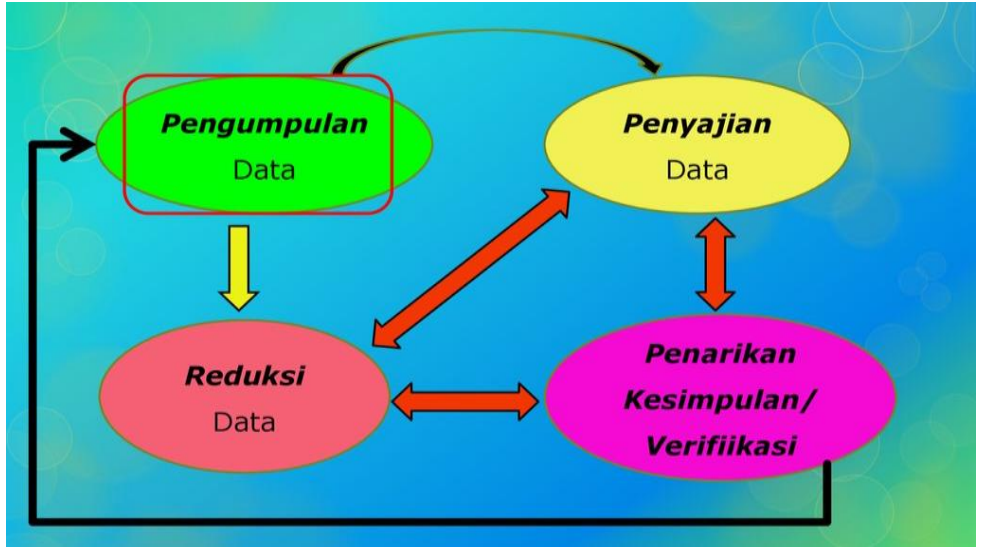

Gambar. 1. Analisis Data (Miles \& Huberman)

\section{HASIL DAN PEMBAHASAN}

Pendidikan Islam pada Suku Bajo di Kecamatan Abeli Kendari masih "tergolong rendah serta belum terlaksana dengan baik atau kualitas sumber daya manusia belum memenuhi target. Indikatornya adalah dimana orang tua belum terlalu maju pemikiran tentang pentingnya pendidikan Islam untuk menyertai anak dalam memandu hidupnya dimasa yang akan datang, terutama dalam pengalaman nilai-nilai keimanan dan keislaman sebgai agama yang paling tertinggi untuk meraih takwa yang hakiki" (Mastang (Tokoh Masyarakat), Wawancara : 2020). Hal ini menjadi faktor yang membuat anak-anak suku bajo banyak putus sekolah. Hal sesuai dengan hasil penelitian tentang suku bajo yang menyimpulkan bahwa faktor internal yang menjadi penyebab utama banyaknya anak putus sekolah berhubungan dengan rendahnya minat dan motivasi anak untuk sekolah di samping adanya persepsi yang keliru tentang arti pendidikan. Persepsi orang tua tentang arti penting pendidikan yang keliru, faktor ekonomi serta faktor lingkungan pergaulan anak-anak setempat (Manguntara \& Iba, 2015).

Sistem pendidikan dan pembelajaran yang digunakan belum mampu membangkitkan minat dan semangat anak-anak suku Bajo yang ada di pesisir Kecamatan Abeli Kota Kendari. Sehingga banyak ditemukan anak putus sekolah pada suku Bajo di Kecamatan Abeli. Mengingat metode pembelajaran belum begitu efektif khususnya bagi anak-anak suku Bajo, maka perlu dikembangkan pada pembelajaran alternatif yang sesuai/adaptif dengan konteks budaya masyarakat setempat. "Salah satu pendidikan alternatif yang dapat dikembangkan adalah menanamkan nilai-nilai keimanan serta keislaman pada seorang anak, lewat pendidikan informal dimana orang tua selain kegiatan memancing di laut juga mengajari anak-anak untuk membaca al-Qur'an serta mengajari anaknya shalat. Selain itu juga tidak kala pentingnya memberikan keteladanan yang baik. Pendidikan merupakan suatu proses yang disengaja dan berkesinambungan dalam mengembangkan fitrah dan fungsi manusia, akan memberikan hasil yang maksimal bila menggunakan paradigma proses pendidikan yang menekankan pada pembelajaran sebagai suatu proses" (Kamaruddin (Tokoh Masyarakat), Wawancara: 2020). Hal ini sesuai dengan hasil penelitian lain yang menyimpulkan bahwa perubahan paradigma masyarakat Muslim suku Bajo yang awalnya memandang pendidikan belum penting menjadi penting. Terungkap berbagai kendala yang di hadapi masyarakat Muslim suku Bajo Wuring dalam dunia pendidikan diantaranya adalah kebiasaan suku Bajo melibatkan anak-anak usia sekolah dalam mencari ikan dilaut serta pendapatan perkapita yang rendah dalam suku Bajo Wuring sebagai nelayan tradisional mengakibatkan sulitnya mereka dalam melanjutkan pendidikan anaknya (Suryadi \& Tinus, 2015). Kehidupan suku Bajo sangatlah dekat dengan laut. Laut dapat dipandang sebagai budaya (tradisi) tersendiri yang mengacu pada kepercayaan dan praktek yang mengatur kehidupan manusia yang relevan termasuk cara bagaimana budaya-budaya ini dikonseptualisasikan, dibatasi, distrukturkan, dan di atur (Dai \& Manahung, 2020). 
Salah satu cara untuk mendidik anak-anak saya ketika saya pulang dari laut, setelah selesai shalat dzuhur langsung saya duduk di tengan-tengah mereka untuk mengajarkan membaca al-qur'an dengan sistem mengeja, setelah selesai engaji maka saya lengsung memberikan wejangan kepada anak tentang pentingnya yang namanya akhlak mulia, karena meskipun saya hanya tamat sekolah dasar tetap saya menjunjung tinggi nilai-nilai moral, karena sangat penting artinya dalam ukhuwah Islamiyah (Abdul Malik, Wawancara: 2020). Pembelajaran yang mendekatkan anak pada alam sekitar dan kehidupan nyata dalam suasana yang menyenangkan, dikaitkan dengan nilai-nilai Aqidah dan akhlaq dan pendekatan orang tua sebagai "uswatun Hasanah" dapat mengembangkan kecerdasan intelektual, emosional dan spritual anak. Untuk menghasilkan proses pendidikan yang baik, maka peningkatan kualitas guru menjadi prioritas utama. Karena menurut United Nations Development Programme (UNDP), mutu sekolah ditentukan oleh Guru (48\%), Manajemen (30\%) dan Sarana (22\%) (Lailatussaadah, 2015).

Untuk apa anak-anak menghabiskan waktu duduk di kelas sementara dengan pergi melaut mereka bisa menangkap ikan dan menghasilkan uang. Oleh karena itu, banyak orang tua Suku Bajo tidak berkenan anak-anaknya sekolah. "Mereka tidak bisa disalahkan, karena kurikulum sekolah yang ada tidak sesuai dengan lingkungan kehidupan mereka. Ada jarak antara sekolah dengan masyarakat Suku Bajo, baik secara fisik, psikologis maupun sosiologis," tutur Abdul Manan. Karena itulah kini pemda setempat bekerja sama dengan Direktorat Pendidikan Dasar Kemendikbud membangun sekolah di lingkungan masyarakat Bajo. Mata pelajarannya disesuaikan dengan kebutuhan masyarakat setempat (Abdul Manan, Wawancara: 2020). Pembelajaran Eksploratif di kenal pada suku Bajo adalah sistem pembelajaran yang menjadikan alam dan lingkungan sekitarnya sebagai medianya dengan mengintegrasikan beberapa mata pelajaran dalam tema-tema alam dan lingkungan, dan pembelajaranya dilakukan secara di luar kelas sehingga meningkatkan kualitas keimanan, akhlak mulia, kesadaran lingkungan kesemuanya terwujud melalui perilaku sehari-hari (Safar, Wawancara: 2020).

Perkembangan ilmu dan teknologi sudah mulai bergeser pada pendekatan alam, Tiga aspek utama yang dapat diteladani dari fenomena alam, yaitu : 1). Menjadikan alam sebagai contoh dan sumber belajar. 2). Inspirasi untuk mencari penyelesaian baru. 3). Menjadikan alam sebagai guru, dan pembimbing. 4). Penentu nilai yang sesuai dan yang merusak. 5). Menjadikan alam sekitar sebagai standar ukuran tentang rekayasa dan inovasi yang ramah alam dan lingkungan.( Abdul Manan, Wawancara : 2020). Nilai-nilai leluhur Suku Bajo dalam membangun sikap bertoleransi, tercermin dari nilai-nilai kehidupan masyarakat Suku Bajo sehari-hari yang sudah mendarah daging dalam sikap hidupnya. Dari nilai keselarasan, dimana masyarakat Suku Bajo meyakini keselarasan dengan alam dan juga manusia, dalam menjaga keseimbangan laut, sebagai sumber kehidupan bagi masyarakat Bajo. Hidup berdampingan, merupakan kecenderungan untuk menghindari konflik, membuat masyarakat Suku Bajo tidak mudah terprovokasi (Syefriyeni \& Rosie, 2020).

Mengembangkan metode biomimikri di Indonesia dalam perspektif Islam yang berkaitan dengan masyarakat Bajo pada khususnya sangat memungkinkan, Islam mengajarkan bahwa segala potensi dan lingkungan bisa dijadikan sumber pendidikan Islam sehingga kekayaan sumber daya alam dan keanekaragaman hayati yang dimiliki Indonesia tidak ternilai harganya tidak lepas dari materi pendidikan Islam, tidak saja untuk bangsa Indonesia, tetapi juga umat manusia di dunia ini. Keberagaman hayati ini menunjukan kebesaran dan kekuasaan Allah swt.

Adapun sarana dan prasarana pendidikan pada pemukiman suku Bajo di lingkungan terdekat di Kelurahan Talia dan Kelurahan Tononggeu kecamatan Abeli Kendari sebagaimana disajikan pada tabel 1. Dari tabel 1 menunjukkan bahwa banyak lembaga pendidikan anak usia dini yang ada disekitar permukiman suku Bajo. Adapun faktor pendukung pelaksanaan pendidikan Islam pada anak masyarakat suku Bajo di Kota Kendari. Bahwa masyarakat suku Bajo di Kota Kendari seratus persen beragama Islam, sebagian besar 
keluarga suku Bajo yang tinggal dipesisir namun sebagian kecil pernah mengenyam pendidikan serta perhatian pemerintah setempat sudah aktif memberikan fasilitas dan bantuan dalam rangka untuk menunjang kehidupan masyarakat Bajo.

\section{Tabel, 1 Nama-nama Sekolah di sekitar permukiman suku Bajo}

\begin{tabular}{lll}
\hline No & Nama Lembaga Pendidikan & Keterangan \\
\hline 1 & Taman Kanak-kanak Al-Falah & Yayasan Pend. Islam \\
2 & Taman Kanak-Kanak Al-Munawarah & Yayasan Pend. Islam \\
3 & Taman Kanak-Kanak Asyafiiyah & Yayasan Pend. Islam \\
4 & Taman Kanak-Kanak Al-Ridha & Yayasan Pend. Islam \\
\hline
\end{tabular}

Sumber data Kecamatan Abeli Kota Kendari Tahun 2019.

Pengakuan suku Bajo terhadap agama Islam sebagai agamanya menjadi modal dasar dalam pengembangan pendidikan Islam, namun menurut pernyataan $\mathrm{H}$. Abdul Jabbar, bahwa: walaupun realitasnya masih ada suku Bajo yang belum mampu melafazkan kalimat syahadat dengan baik dan benar, belum sempurnah mendirikan shalat lima kali dalam sehari semalam secara disiplin, belum sempurnah melaksanakan puasa di bulan ramadhan, masih jarang mengeluarkan zakat baik zakat fitrah maupun zakat harta. Namun telah menjadikan agama Islam sebagai pilihan satu-satunya bagi masyarakat suku Bajo sebagai sarana untuk mendapatkan pencerahan berupa nasehat, siraman rohani dan pendidikan Islam untuk menambah kekuatan keyakinan dalam memahami secara sempurna.(H. Abdul Jabbar Tokoh Agama, Wawancara : 2020). Pada umumnya masyarakat suku bajo beragama Islam, akan tetapi mereka tetap juga mempercayai roh-roh leluhur yang ada dilaut. Sehingga budaya melaut yang dilakukan tidak terlepas dari mantra-mantra yang dilontarkan disertai dengan sesajen-sesajen yang dibuang ke laut yang dipersemkan buat dewa laut (Nurhaliza \& Suciati, 2019).

Motivasi nilai-nilai agama masyarakat suku Bajo banyak mendapatkan perhatian seperti tidak turun di laut pada hari jum'at, lebih memilih tinggal jum'at dari pada pergi malaut. Ini berarti menunjukkan bahwa masyarakat suku Bajo sudah dapat meningkatkan keimanan dan ketakwaan kepada Allah SWT. Hal senada diungkapkan oleh salah seorang tokoh masyarakat sebagai berikut: Ketika raja Bone mengajak raja kendari memeluk Islam dan penaklukan Kendari oleh Belanda, suku Bajo menjadi sasaran di teluk Kendari. Ketika sang raja menerima Islam sebagai agamanya maka masyarakat juga menerima Islam termasuk suku Bajo yang ada dipesisir yang sangat hormat pada raja, karena perlakuan dan penghargaan khusus raja Bone kepada suku Bajo yang merasa sangat berkesan sehingga betah tinggal dan mempertahankan kerajaan Kendari dari serangan arah laut. Penerimaan agama Islam oleh leluhur Bajo di warisi secara turun temurun oleh generasi suku Bajo yang ada di pesisir kota Kendari (H. Samsuddin, Tokoh Agama, Wawancara : 2020).

Pengakuan suku Bajo terhadap agama Islam tersebut menjadi faktor pendukung dan terlaksananya pendidikan Islam pada anak suku Bajo di Kecamatan Abeli Kendari. Dampak positif yang muncul akibat perubahan sosial tersebut yaitu munculnya kesadaran pendidikan, terciptanya lapangan pekerjaan baru, meningkatnya taraf hidup, dan modernisasi sistem perikanan. Sedangkan dampak negatif yang ditimbulkan yaitu semakin berkurangnya eksistensi adat istiadat, reorientasi pandangan hidup, serta mulai munculnya pola hidup konsumtif (Suryanegara et al., 2015). Program-program pemerintah yang masuk di komunitas Suku Bajo, walaupun demikian, tidak dapat dipungkiri juga membawa perubahan sosial positif yang secara langsung sudah dirasakan manfaatnya oleh Suku Bajo. Pembangunan sarana prasarana pendidikan, kesehatan, ekonomi berupa simpan pinjam kelompok perempuan, dan pariwisata budaya terbukti telah mengubah wajah komunitas Suku Bajo di pesisir teluk Tomini yang sebelumnya kumuh dan terpencil menjadi lebih modern (Obie, 2016). 
Reaksioner yang dimaksudkan bagi suku Bajo adalah tidak membangkang atau tidak suka melawan apabila merasa di intimidasi atau ditekan. Suku Bajo dikenal suku yang ramah, damai, bersahabat serta memiliki semangat yang tinggi, namun tidak agresif dan tidak iri hati dalam menghadapi persaingan baik sesama suku Bajo maupun terhadap suku lain, sehingga begitu merasa diganggu, dihina dan dibentak maka mereka lebih baik meninggalkan tempatnya untuk mencari tempat lain demi untuk mendapatkan keamanan dan kedamaian sebagai tempat mencari rezki untuk menopang hidupnya dimasa depan. Dengan semudah itu mereka meninggalkan tempat tinggalnya jika tidak mendapatkan kedamaian karena mereka mereka memiliki alat transportasi berupa perahu. Oleh karena itu, masyarakat suku Bajo semakin sadar arti pendidikan dalam kehidupan, sejak adanya program pemerintah tentang wajib belajar 9 tahun maka anak suku Bajo memasukan anaknya untuk mengenyam pendidikan tersebut agar sejajar dengan suku-suku lain yang ada di Kecamatan Abeli kendari. Terkait dengan itu salah seorang informan menjelaskan, Tahang menjelaskan bahwa: Sejak tahun 1970 setelah dimukimkan dalam sebuah perkampungan khusus yang diperuntukkan bagi masyarakat suku Bajo di pesisir pantai Kecamatan Abeli, maka mulai terjadi pembaruan bagi anak-anak mereka berminat untuk bersekolah, karena dasar orang tuanya pernah mengenyam pendidikan pada waktu dahulu, sehingga terwujud harapan orang tunya seandainya orang tua mereka tidak memiliki pemikiran pendidikan maka boleh jadi tidak ada dorongan yang ditularkan pada anaknya, berbeda dengan orang tua yang tidak sekolah meka besar kemungkinan kecil motivasi yang timbul dari orang tua bahkan boleh dikatakan tidak ada (Tahang, Tokoh Agama, Wawancara:2020).

Posisinya yang terletak di pesisir pantai teluk kendari dengan buatan rumah panggung, di atas laut dari perumahan tersebut terdapat tempat pengajian bagi anak-anak baik tingkat pemula maupun maupun tingkat lanjutan sekalugus anak-anak mereka belajar tata cara shalat secara berjamaah, mendengarkan riwayat orang-orang yang berhasil dalam mendakwakan Islam. Juga tidak terlepas perhatian pemerintah untuk mendirikan sekolah di perkampungan masyarakat suku Bajo yang ada di Kota kendari. Ada secercah pendidikan dan pelajaran yang saya dapatkan dari pengalaman hidup berBajo masyarakat Suku Bajo, yang sekaligus dapat menjadi refleksi saya kemudian. Masyarakat Suku Bajo adalah masyarakat yang tidak bisa lepas dari debur ombak dan putihnya buih yang diperkuat oleh melodi suara burung pemakan ikan. Suatu masyarakat yang memiliki aturan berperilaku, serta memiliki pola pikir yang didasarkan pada fenomena alam yang mengitarinya. Karakter dan sikap mereka tidak jauh berbeda dengan mereka yang berada di wilayah kepulauan di seluruh nusantara. Hal ini adalah ciri umum dan utama dari masyarakat Suku Bajo. Bagian rumah pasti selalu berhubungan dengan laut. Walaupun ada bererapa rumah yang mengkombinasikan antara daratan dan lautan (Ali, 2017).

Hal tersebut senada dengan pernyataan salah seorang tokoh agama, Saleh mengatakan, bahwa: salah satu faktor pendukung bagi anak-anak dalam memenuhi tuntutan zaman, karena meski orang tua suku Bajo agak minim memiliki pendidikan yang lebih tinggi, tetapi antusias untuk memotivasi anak untuk belajar pendidikan Islam berupa belajar mengaji, menularkan kepada anaknya tentang tata cara bertutur kata yang baik. Itu semua berkat adanya taman pengajian al-Qur'an (TPA) yang ada di tempat kami, maka alhamdulillah anak kita sudah mampu membaca dan menulis huruf al-Qur'an. Apalagi pemerintah dalam hal ini kepala kelurahan memberikan insentif setiap bulan kepada guru mengaji sebagai imbalan dari kerja mereka (Saleh, Orang tua, wawancara : 2020). Persepsi Suku Bajo tentang pendidikan Islam, dapat dilihat dalam bentuk sikap, motivasi, minat, pengetahuan dan pengalaman, kepentingan dan harapan yang masih negatif, rendah dan kurang perhatian, karena sekolah bagi mereka merupakan gangguan yang menyita waktunya untuk mencari ikan di laut, pendidikan tidak dijadikan sebagai sarana untuk meningkatkan harkat dan martabat, bahkan merasa bahwa pendidikan bukan diperuntukkan bagi suku Bajo sehingga kurang diminati dan belum tertarik karena alasan ekonomi dan persepsi yang masih kabur (Katutu, 2016). 
Orang tua suku Bajo yang pernah sekolah maka menjadi motivator agar anak-anaknya dapat bersekolah sehingga anak-anak mereka lebih maju dan lebih arif ketimbang anak yang memiliki orang tua yang tidak pernah bersekolah, sudah mempunyai pengetahuandan pengalamanyang sangat positif jika dibandingkan orang tua yang tidak pernah sekolah. Kondisi demikian berpengaruh terhadap perubahan dan perkembangan anak-anak suku Bajo dalam pendidikan formal sekaligus membangun animo anak-anak suku bajo untuk bersekolah.

Pada tahun terakhir ini, sudah terjadi regenerasi yang mempunyai zaman yang berbeda dengan orang tuanya, sehingga dengan perubahan dan pembaruan maka kondisi dan prestasi pembelajaran mulai menunjukkan hasil yang lebih positif, terutama orang tua suku Bajo pernah menikmati pendidikan disekolah. Maka dengan keluarnya peraturan pemerintah tentang wajib balajar 9 tahun, sudah banyak orang tua masyarakat suku Bajo yang menyekolahkan anaknya.

Proses pemberdayaan masyarakat marginal termasuk masyarakat Bajo di Kecamatan Abeli, dapat dilakukan melalui delapan langkah, yaitu (1) menyusun kelompok kecil sebagai penerima awal atas rencana pemberdayaan, (2) mengidentifikasi/membangun kelompok warga belajar, (3) memilih dan melatih fasilitator kelompok, (4) mengaktifkan kelompok belajar, (5) menyelenggarakan pertemuan-pertemuan fasilitator, (6) pendukung aktivitas kelompok sedang berjalan, (7) mengembangkan hubungan di antara kelompok, dan (8) menyelenggarakan sebuah lokakarya untuk evaluasi. Dalam pemberdayaan melalui pendidikan, para pendidik berfungsi penolong atau fasilitator orang lain untuk berkembang. (H. Samsuddin, Tokoh Agama, wawancara:2020).

Kontribusi pelaksanaan pendidikan Islam pada anak suku Bajo di Kecamatan Abeli Kendari sangat minim, sesuai dengan kenyataan, masyarakat Bajo di Kecamatan Abeli Kendari atau biasa disebut juga orang laut masih banyak yang buta huruf. Budaya fasalistik juga masih melekat kuat dalam kepribadian mereka, seperti kurang kreatif dan produktif, cepat puas dengan apa yang diperoleh, pasrah pada nasib, sikap konsumtif dan boros, serta sikap menutup diri pada pihak-pihak lain. Hal ini diperkuat dengan pendapat yang dikemukakan Marsan mengatakan, "penyebab ketertinggalan bidang pendidikan bagi Suku Bajo khususnya yang tinggal di pesisir adalah kurangnya animo orang tua untuk menyekolahkan anaknya pada pendidikan formal, agak jauh lembaga pendidikan formaldi kawasan permukiman masyarakat suku Bajo" (Marsan Tokoh masyarakat, Wawancara, 2020). Keadaan tersebut membuat Suku Bajo sama sekali kurang tertarik dengan pendidikan dan enggan pergi sekolah. Lebih lanjut Marsan mengatakan bahwa "saat ini pendidikan bagi etnis Bajo masih sangat jauh dari yang diharapkan, permasalahannya masih berkutat pada belum relevannya sistem pendidikan bagi etnis Bajo" (Marsan Tokoh masyarakat, Wawancara, 2020).

Anak-anak Bajo di pesisir Kecamatan Abeli Kendari menurut Marsan memerlukan pendidikan alternatif dan kesesuaian dalam belajar untuk mengantarkan masyarakat Bajo masa depan yang lebih berpendidikan dan mampu sejajar dengan etnis lain di Sulawesi Tenggara yang selangkah lebih maju ketimbang etnis Bajo. Pendidikan Islam anak suku Bajo di pesisir Kota Kendari akan berlangsung dalam sanggar dan alam bebas dengan kegiatankegiatan bimbingan baca tulis dan hitung serta pemberian pelatihan keterampilan kecakapan hidup serta aksi tanggap lingkungan. Keterampilan kecakapan hidup yang akan diberikan lebih bersifat keterampilan kejuruan yang telah ada basisnya dalam kehidupan masyarakat Bajo di pesisir Kota Kendari seperti budidaya ikan, budidaya rumput laut, pengeringan ikan, pembuatan kerupuk atau kue-kue dari hasil-hasil laut, dan lain-lain (Marsan Tokoh masyarakat, Wawancara, 2020).

Kerja sama yang terpadu selaras antara tripusat pendidikan dalam pembinaan anak sangat penting dalam membentuk keperibadian anak khususnya pada masyarakat Bajo di Kecamatan Abeli Kendari, agar anak tidak mengalami hambatan dalam pertumbuhan dan perkembanganya. Jangan sampai terputus antara pendidikan keluarga dan pendidikan sekolah, atau antara pendidikan sekolah dengan pendidikan masyarakat disebabkan oleh 
orang tua atau orang dewasa yang dibari amanah tidak melaksanakan tanggung jawab itu secara wajar dan profesional. kerjasama dengan pihak orang tua dengan melakukan komunikasi efektif berkaitan dengan kegiatan pembelajaran yang dilakukan selama pembelajaran dari rumah karena pelaksana kegiatan adalah orang tua. Berikan penjelasan mengenai pentingnya memberikan stimulasi sejak dini dan melakukan laporan kegiatan anak kepada guru melalui artikel-artikel ataupun melalui komunikasi langsung. Kegiatan dapat berupa perencanaan yang telah dirancang dari lembaga ataupun kegiatan yang dilakukan bersama orang tua di rumah (Maryani, 2020).

Sudah menjadi sunnatullah bahwa sang ayah mendapat tugas sebagai pemimpin dalam keluarganya karena kemampuan jasmaninya, keteguhan hati, kecerdasan berfikir dan kecakapan bertindak dalam mencari rezki. Demikian juga sang ibu menjadi pemimpin terhadap anak-anaknya di rumah sehingga menjadilah ibu sebagai suatu lembaga yang dapat membina anggota rumah tangganya sebagai suatu amanah menuju terbentuknya generasi yang saleh, kuat dan sehat. Terkait dengan pelaksanaan pendidikan Islam di rumah, Hasan mengemukakan bahwa: Anak usia tiga hingga enam tahun masyarakat Suku Bajo pada umumnya hanya tinggal di rumah bersama ibunya, yang sepanjang hari kebanyakan bermain ditanggul dan mandi di pinggir laut sambil menunggu orang tuanya kembali dari melaut. Anak-anak Suku Bajo pada umumnya pandai berenang pada umur lima tahun sehingga anak laki-laki dapat membantu mengangkat ikan dari perahu atau kapal ke darat atau ke tanggul, sambil mengumpulkan hasil untuk dikomsumsi atau dijual. Hasil penjualannya menjadi uang jajan yang dapat di belanjakan sepanjang hari di tanggul dengan berbagai jajanan kue, kerupuk, bakso, somay, dan sebagainya. Namun, hanya sewaktu-waktu mereka kembali ke rumah untuk makan siang, tidur, mengikuti pengajian Al-Qur'an. Pada sore hari bukan hanya anak-anak yang bermain di tanggul, tetapi para remaja dan kaum ibu Suku Bajo beramairamai duduk bercengkrama sambil menunggu suaminya pulang dari melaut (Hasan, orang tua, Wawancara: 2020). Pengasuhan anak usia dini di suku laut desa mola selatan kabupaten wakatobi menggunakan pengasuhan yang memanjakan atau indulgent parenting, di mana orang tua sangat terlibat dengan anak-anak mereka hal ini terlihat dari keterlibatan oleh tua dalam segala aktivitas anak mereka baik di sekolah maupun di rumah (Hewi, 2019). Dalam keluarga, peranan orang-tua maupun saudara berpengaruh dalam membentuk kepribadian anak. Pola asuh dari orang-tua yang baik akan melahirkan perilaku yang baik pula bagi anak (Machmud, 2021). Menjadi orang tua yang kreatif yaitu dapat menciptakan lingkungan belajar yang menyenangkan dan kondusif, orang tua dapat dengan sabar memberikan stimulus berupa materi-materi yang diberikan oleh guru-gurunya (Anisyah et al., 2021).

Orang tua dari suku Bajo mempunyai berbagai macam tuntutan yang harus dilakukan oleh anak-anaknya, seperti menghapal surah-surah pendek Al-Qur'an, mengahapal doa-doa yang berkaitan dengan kehidupan sehari-hari atau menyampaikan kisah-kisah kenabian dan sejarah perjuangan para sahabat Nabi atau pembela tanah air. Hal tersebut terjadi karena, para ibu tidak mempunyai wawasan seperti itu dan pada umumnya kaum ibu tidak tamat SD sehingga pengetahuan dan pengalamannya sangat terbatas untuk memberikan pembinaan secara memadai. Berdasarkan hasil penelitian Ikhsan menyimpulkan bahwa perspektif nelayan di kampung Bajo memandang: 1) pendidikan sebagai hal yang tidak terlalu penting sebab anak nelayan harus membantu orang tua untuk melaut, 2) Anak nelayan di Kampung Bajo tidak perlu sekolah tinggi-tinggi karena ujung-ujung nya juga mereka akan menjadi pelaut sebagaimana nenek moyang mereka, 3) kurangnya motivasi bagi anak nelayan untuk melanjutkan pendidikan dan mereka lebih memilih ikut orang tua melaut untuk mencari uang, dan 4) kurangnya dorongan orang tua kepada anak untuk melanjutkan pendidikan formal (Ikhsan et al., 2020).

Orang tua menjadi pemikul amanah dari Allah swt. agar bertanggung jawab dalam memelihara, merawat, membimbing dan mendidik anak-anaknya secara ikhlas dan kodrati, penuh kasih sayang akrab dan intim sebagai pendidik pertama dan utama dalam menanamkan nilai-nilai akidah dan Islam, akhlak dan shalat melalui pembiasaan memberikan 
contoh pada anak dalam rumah tangga. Hasil penelitian Tanjung menyimpulkan bahwa orang tua mengkondisikan lingkungan keluarga sebaik mungkin untuk menunjang pendidikan anak, hal ini dibuktikan dengan diputarkan ayat-ayat Al-Qur'an setiap malam, orang tua selalu meluangkan waktu untuk anak dan komunikasi yang baik dalam keluarga (Tanjung, 2020). Dengan demikian, orang tua mempunyai peranan dan pengaruh yang besar dalam pembentukan kepribadian anak, sekaligus menjadi pamungkas terhadap hambatan yang dihadapi oleh anak. Oleh karena itu, orang tua menjadi pelatih serta pemegang kunci utama dalam mengantarkan anak dalam penyesuaian pribadi, sosial dan keterampilan.

\section{SIMPULAN}

Pendidikan Islam pada Suku Bajo di Kecamatan Abeli Kota Kendari masih tergolong rendah serta belum terlaksana dengan baik atau kualitas sumber daya manusia belum memenuhi target. Faktor pendukung pelaksanaan pendidikan Islam pada anak masyarakat suku Bajo di Kota Kendari. Bahwa masyarakat suku Bajo di Kota Kendari seratus persen beragama Islam, sebagian besar keluarga suku Bajo yang tinggal dipesisir namun sebagian kecil pernah mengenyam pendidikan serta perhatian pemerintah setempat sudah aktif memberikan fasilitas dan bantuan dalam rangka untuk menunjang kehidupan masyarakat Bajo. Orang tua dari suku Bajo mempunyai berbagai macam tuntutan yang harus dilakukan oleh anak-anaknya, seperti menghafal surah-surah pendek Al-Qur'an, mengahapal doa-doa yang berkaitan dengan kehidupan sehari-hari atau menyampaikan kisah-kisah kenabian dan sejarah perjuangan para sahabat Nabi atau pembela tanah air.

\section{UCAPAN TERIMA KASIH}

Tim penulis mengucapkan terima kasih kepada masyarakat suku Bajo di Kecamatan Abeli Kota Kendari khususnya tokoh agama, tokoh adat, tokoh masyarakat, kepala desa dan tokoh pemuda yang telah meluangkan waktu untuk membantu penelitian ini sehingga dapat terlaksana. Terakhir, kepada pengelola dan para reviewer Obsesi : Jurnal Pendidikan Anak Usia Dini yang telah memberikan masukan perbaikan sehingga artikel ini bisa di publikasi.

\section{DAFTAR PUSTAKA}

Ali, M. (2017). Mengkomunikasikan Pendidikan dan Melestarikan Kearifan Lokal Orang Bajo. INFERENSI, 11(1), 187. https:// doi.org/10.18326/infsl3.v11i1.187-206

Anisyah, N., Indrawati, Hafizotun, L., Marwah, S., Yumarni, V., \& Annisa DN, N. (2021). Orang Tua Kreatif untuk Anak Usia Dini di Masa Pandemi Covid-19 Melalui Kegiatan Parenting. Murhum: Jurnal Pendidikan Anak Usia Dini, 1, 34-43. https:// doi.org/10.37985/murhum.v2i1.26

Ayuni, D., Marini, T., Fauziddin, M., \& Pahrul, Y. (2021). Kesiapan Guru TK Menghadapi Pembelajaran Daring Masa. Jurnal Obsesi : Jurnal Pendidikan Anak Usia Dini, 5(1), 414-421. https://doi.org/10.31004/obsesi.v5i1.579

Chairilsyah, D. (2019). Analisis Kemandirian Anak Usia Dini. PAUD Lectura: Jurnal Pendidikan Anak Usia Dini, 3(01), 88-98. https://doi.org/10.31849/paudlectura.v3i01.3351

Christianti, M. (2015). Profesionalisme Pendidik Anak Usia Dini. Jurnal Pendidikan Anak, 1(1), 112-122. https://doi.org/10.21831/jpa.v1i1.2923

Dai, F. H., \& Manahung, R. (2020). Kearifan Lokal Masyarakat Suku Bajo Studi Etnografi NilaiNilai Pendidikan Agama Islam dan Budi Pekerti Pada Praktek Ritual Keagamaan di Desa Bajo Kecamatan Tilamuta. Pendidikan Islam Dan Budi Pekerti, 1(1), 41-57. 
Dozan, W., \& Fitriani, L. (2020). Membangun Karakter Anak Usia Dini Melalui Nilai-Nilai Islam Dalam Tradisi Perang Timbung. Murhum : Jurnal Pendidikan Anak Usia Dini, 1(1), 1-15. https:// doi.org/10.37985/murhum.v1i1.2

Hewi, L. (2015). Kemandirian Usia Dini Di Suku Bajo (Studi Kasus pada Anak Usia 4-6 Tahun di KB Nur' Ain Mola Selatan Kabupaten Wakatobi Provinsi Sulawesi Tenggara tahun 2015). JPUD - Jurnal Pendidikan Usia Dini UNJ, 9(1), 75-92. https://doi.org/10.21009/JPUD.091.05

Hewi, L. (2019). Pengasuhan Anak Usia Dini Di Suku Laut Kabupaten Wakatobi. Jurnal Golden Age, 3(02), 73. https:// doi.org/10.29408/goldenage.v3i02.1644

Ikhsan, A. M., Hasriyanti, H., \& Syarif, E. (2020). Pendidikan Formal Anak Dalam Perspektif Nelayan Suku Bajo di Kampung Bajo. LaGeografia, 18(3), 269. https://doi.org/10.35580/lageografia.v18i3.13606

Katutu, A. (2016). Persepsi dan Tingkat Partisipasi Suku Bajo Terhadap Pedidikan Islam. AlQalam, 20(1), 151. https:// doi.org/10.31969/alq.v20i1.169

Khadijah, K., \& Amelia, N. (2020). Asesmen Perkembangan Kognitif Anak Usia 5-6 Tahun. AlAthfaal: Jurnal Ilmiah Pendidikan Anak Usia Dini, 3(1), 69-82. https://doi.org/10.24042/ajipaud.v3i1.6508

Lailatussaadah, L. (2015). Upaya Peningkatan Kinerja Guru. Intelektualita, 3(1).

Machmud, H. (2021). Membingkai Kepribadian Anak dengan Pola Asuh pada Masa Covid 19. Murhum: Jurnal Pendidikan Anak Usia Dini, 1, 44-55. https:// doi.org/10.37985/murhum.v2i1.24

Machmud, H., Alim, N., \& Ulviya, L. (2020). Keterampilan Sosial Anak Suku Bajo di Sulawesi Tenggara. Jurnal Obsesi: Jurnal Pendidikan Anak Usia Dini, 4(2), 787. https://doi.org/10.31004/obsesi.v4i2.459

Manguntara, L., \& Iba, L. (2015). Strategi Penanganan Anak Putus Sekolah pada Suku Bajo Melalui Optimalisasi Peran Komite Sekolah di Kecamatan Tiworo Kabupaten Muna. ETNOREFLIKA, 4(3), 934-946. https:/ / doi.org/10.33772/etnoreflika.v4i3.230

Maryani, K. (2020). Penilaian dan Pelaporan Perkembangan Anak Saat Pembelajaran di Rumah di Masa Pendemi Covid-19. Murhum: Jurnal Pendidikan Anak Usia Dini, 1(1), 41-52. https:// doi.org/10.37985/murhum.v1i1.4

Mastuti, D. (2014). Kesiapan Taman Kanak-Kanak Dalam Penyelenggaraan Kelas Inklusi Dilihat Program Kegiatan Pembelajaran. BELIA: Early Childhood Education Papers, 3(1). https://doi.org/10.15294/BELIA.V3I1.3274

Musya'Adah, U. (2020). Peran Penting Pendidikan Agama Islam di Sekolah Dasar. Aulada: Jurnal Pendidikan Dan Perkembangan Anak, 2(1), 9-27. https://doi.org/10.31538/aulada.v2i1.556

Nurhaliza, W. S., \& Suciati, T. N. (2019). Potret Sosial Budaya Masyarakat Suku Bajo Sampela di Kabupaten Wakatobi. Jurnal Komunikasi Universitas Garut: Hasil Pemikiran Dan Penelitian, 5(2), 341-356. https:// doi.org/10.10358/jk.v5i2.671.g639

Obie, M. (2016). Perubahan Sosial Pada Komunitas Suku Bajo Di Pesisir Teluk Tomini. AlTahrir: Jurnal Pemikiran Islam, 16(1), 153. https://doi.org/10.21154/altahrir.v16i1.377

Poelinggomang, E. L. (2016). Makassar abad XIX (Studi tentang Kebijakan Perdagangan Maritim). Kepustakaan Populer Gramedia. 
Saihu, S. (2020). Konsep Pembaharuan Pendidikan Islam Menurut Fazlurrahman. Andragogi: Jurnal Pendidikan Islam Dan Manajemen Pendidikan Islam, 2(1), 82-95. https:// doi.org/10.36671/andragogi.v2i1.76

Shaleh, M., \& Anhusadar, L. (2021). Kesiapan Lembaga PAUD dalam Pembelajaran Tatap Muka pada New Normal. Jurnal Obsesi : Jurnal Pendidikan Anak Usia Dini, 5(2), 21582167. https://doi.org/10.31004/obsesi.v5i2.1139

Suryadi, S., \& Tinus, A. (2015). Paradigma Pendidikan Masyarakat Muslim Suku Bajo Wuring Kabupaten Sikka. Jurnal Kebijakan Dan Pengembangan Pendidikan, 3(2). https:// doi.org/10.22219/jkpp.v3i2.11560

Suryanegara, E., Suprajaka, \& Nahib, I. (2015). Perubahan Sosial Pada Kehidupan Suku Bajo: Studi Kasus Di Kepulauan Wakatobi , Sulawesi Tenggara ( Social Change on Bajo Tribe : Case Study in Wakatobi Islands , Southeast Sulawesi ). Majalah Globe, 17(1), 6778.

Syefriyeni, S., \& Rosie, T. A. S. (2020). Nilai-Nilai Leluhur Suku Bajo dalam Membangun Sikap Bertoleransi. Jurnal Intelektualita: Keislaman, Sosial Dan Sains, 9(1), 179-192. https:// doi.org/10.19109/intelektualita.v9i1.5648

Tanjung, R. (2020). Peran Orangtua dalam Pendidikan Anak Usia Dini di Masa Pandemi Covid-19. Murhum: Jurnal Pendidikan Anak Usia Dini, 1(2), 64-73. https://doi.org/10.37985/murhum.v1i2.18 